International Journal of Trend in Scientific Research and Development (IJTSRD) ISSN: 2456-6470

\section{OBJECTIVE OF THE STUDY:}

1) To present overview of Legal obligations on employer covered under Contract Labour Act

2) To present rights of Contractual Labour.

3) To present current scenario of Contractual Labour in India.

\section{RESEARCH METHODOLOGY}

The research is based completely upon the secondary sources of data, which is exploratory related to the subject of the research. Sources of this research include e-journals, web portals and text books etc.,.

\section{LITERATURE REVIEW:}

Contract labour generally refers to "Workers employed by or through an intermediary on work of any establishment". Such labour can be distinguished from the direct workers in terms of employeeemployer relationship and the method of wage payment. The contract labour does not have any direct relationship with the principal employer. It has a distinct way of working unlike in any other classes of labour like permanent, temporary, casual etc. The contract labour system is based on triangular relationship between the user enterprises, the contractors including the sub-contractors as middle man, and the worker. The workers are recruited by an outside agency or person and are supplied to an establishment or engaged on its work. Unlike direct labour, they neither feature on the muster roll of principal employer/ establishment nor are paid directly.

\section{LEGAL DEFINATION}

In India, a legal definition of contract labour is given in Contract Labour (Regulation and Abolition) Act, 1970. According to Section 2(b) of the Contract Labour (Regulation and Abolition) Act, 1970, a workman shall be deemed to be employed as "contract labour" in or in connection with the work of an establishment when he is hired in or in connection with such work by or through a contractor, with or without the knowledge of the principal employer. The expression "employed in or in connection with the work of the establishment" does not mean that the operation assigned to the workman must be a part of, or incidental to, the work performed by the principal employer. Further, workers employed by a licensee for its own benefit are not considered as contract labourers. Similarly, a permanent employee of the contractor who could be placed at different establishments at the choice of the contractor are not called as contract labourer.

\section{SIGNIFICANCE OF CONTRACT LABOUR}

Contract Labour is a significant and growing form of employment. The practice of employing contract labour is observed all over the world and has been in operation since ages. The origin of Contract Labour can be traced back to the emergence of the small scale industries which found it economically unfeasible or unviable to undertake all activities of production process themselves and therefore got some part of work done from workers hired through contractors. The contract workers generally belong to the unorganized sector as they lack bargaining power, have little or no social security and are often engaged in hazardous occupations which could endanger their health and safety. They often have little or no security of employment. However, factors like lack of continuity of work, difficulty in ensuring closer supervision by the employer, higher output or productivity of such workers, cost effectiveness, flexibility in manpower deployment, facilitation for focusing on core competencies, etc., constitute advantages of the system of contract labour.

An article in Hindustan Times in March 2014 mentioned that contract workers make up 46 per cent of workforce of India's largest industrial companies. Businesses need flexibility in dealing with input costs like Labour to maintain operational efficiency. Hence, they would like to keep it variable to remain competitive. However, in order to understand the business need for contract Labour, one must understand its legal, social and capability aspects thoroughly before coming to a conclusion. Laws relating to contract Labour is codified in Contract Labour (Abolition and regulation) Act 1970 and their disputes resolution machinery is defined in Industrial Disputes Act 1947.

\section{PRE INDEPENDENCE STATUS}

Contract labourers were considered as exploited section of the working class mainly due to lack of organisation on their part. Due to this, the Whitely Commission (1860) recommended the abolition of contract labour by implication. Before 1860, in addition to the many disadvantages suffered by the contract labour, the Workmen "e Breach of Contract Act 1959 operated in holding them criminally responsible in the vent of breach of a contract service. 
Subsequent to this, Many Committees were formed by the Government to study the socioeconomic conditions of contract labour like Bombay Textile Labour Enquiry Committee, The Bihar Labour Enquiry Committee, the Rega Committee etc. As a result of these findings, the scope of the definition of "workers" in the Factories Act, 1948, The Mines Act, 1952 and The Plantations Labour Act, 1951 was enlarged to include contract labour.

\section{SALIENT FEATURES OF THE CONTRACT LABOUR ACT ACT 1971}

$>$ Intent \& coverage: The Act provides for regulation of the employment of contract labour and its abolition under certain circumstances. It covers every establishment in which 20 or more workmen are employed on any day of the preceding 12 months as contract labour and every contractor who employs or who employed on any day of the preceding 12 months, 20 or more contract employee. It does not apply to establishments where the work is of intermittent and casual nature unless work performed is more than 120 days and 60 days in a year respectively. (Section 1)

$>$ Advisory Boards: The Act provides for setting up of Central and State Advisory Contract Labour Boards by the central and state governments to advise the respective governments on matters arising out of the administration of the Act. (Section 3 \& 4)

$>$ Registration \& licenses: The establishments covered under the Act are required to be registered as principal employers with the appropriate authorities. Every contractor is required to obtain a licence and not to undertake or execute any work through contract labour, except under and in accordance with the licence issued in that behalf by the licensing officer. The licence granted is subject to conditions relating to hours of work, fixation of wages and other essential amenities in respect of contract as prescribed in the rules. (Section $7 \& 12$ )

$>$ Facilities to contract labours: The Act has laid down certain amenities to be provided by the contractor to the contract labour for establishment of canteens and rest rooms, arrangements for sufficient supply of wholesome drinking water, latrines and urinals, washing facilities and first aid facilities have been made obligatory. In case of failure on the part of the contractor to provide these facilities, the principal employer is liable to provide the same. (Section 16, 17, 18, 19 and 20)

$>$ Payment of wages: The contractor is required to pay wages and a duty is cast on him to ensure disbursement of wages in the presence of the authorised representative of the principal employer. In case of failure on the part of the contractor to pay wages either in part or in full, the principal employer is liable to pay the same. The contract labour that performs same or similar kind of work as regular workmen will be entitled to the same wages and service conditions as regular workmen as per the Rules. (Section 21)

\section{RIGHTS OF CONTRACT LABOUR}

The act determines the rights of the contract labour so as to make them secure from any exploitation. These rights ensure equal status of them as of the workmen and the violation of which is enforceable in court of law. The interests of contract labour are protected in terms of wages, hours of work, welfare, health and social security. Any agreement made between the parties, which is inconsistent with the benefits provided under the Act and are not favorable for the labourers will be treated as invalid.

The contract labours are entitled for the wages including overtime wages and allowances as stipulated for their work at the establishment. It must be paid without delay whenever the wage period is over. It must be in accordance with the Minimum Wages act.

The contract labours have also the right to be provided the safety measures at the establishment and immediate health service in case of any injury to the labour. They are entitled for facilities like rest rooms, canteens, washing facility, first aid facilities and many more. The women labours are entitled for the separate washrooms, restrooms.

$>$ They are entitled not be employed in any work which is prohibited under any law.

\section{CURRENT SCENARIO OF CONTRACTUAL LABOUR}

The size of the contract labour force in India's largest carmaker Maruti Suzuki is reflective of how the corporate world is responding to the changed dynamics of the labour market. The share of contract workers in the automobile company's total workforce has grown from 32 per cent in 2013-14 to 42 per cent in 2015-16. 
Around 55 per cent of the 537 million tonnes of coal mined by public sector behemoth Coal India during 2015-16 was done by 65,000 contractual workers. This ratio is poised to increase to at least 58 per cent in the current financial year.

The Centre remains one of the biggest employers of contract labour. According to the Seventh Pay Commission, the Centre spent Rs 300 crore in 201213 on contract or temporary workers.

The growing demand for contract workers is in line with the global trend of seeking employment flexibility. Over the past 25 years unionisation has fallen across the world. Job outsourcing and dispersal of the workforce in multiple countries have become commonplace even for medium-sized companies in developed countries.

As developing countries like China, Bangladesh, Egypt, Brazil and Colombia are changing their labour laws to permit flexible hiring, developed nations with strong trade unions have been forced to make regulations favouring temporary hiring. Take, for instance, the concept of zero-hour contract, where the employer has no obligation to provide any stipulated hours of work but the employee is required to be available when the employer needs his service. This is the latest example of flexible hiring in Britain.

Trade unions say companies prefer the use of contract workers because of the cost arbitrage. Contract workers are paid much less than regular workers. Legal experts point out lacunae in the law and the fact that the judiciary has interpreted the law in various ways. The Supreme Court in its judgment in the RK Panda vs Steel Authority of India case said workers continuing in employment for 10 years should be absorbed as regular employees. But in a separate case, Steel Authority of India vs National Water Front Workers, the court ruled there was no provision in the law implying absorption of contract workers.

Moreover, the process of hiring contract workers is a tedious one. An organisation with offices across the country has to seek registration by declaring the number of vendors who supply contract workers in each office, based on which forms are issued by separate states. Every vendor in every premise has to seek a licence on that basis. Many companies find ways to subvert the law by hiring contract workers through third-party agents.

\section{CONTRACTUAL LABOUR IN INDIA}

In India, companies, particularly those in labourintensive sectors like automobiles, construction and mining, usually refrain from hiring permanent workers for project-based requirements, as termination requires issuing a notice, payment of compensation, and intimation to the government.

India's inflexible labour laws are said to be a big hindrance for industry. But companies have found a solution by hiring contract workers in large numbers. Newly available data give an idea about the extent and prevalence of this practice at some of India's top listed companies. Contract labours have a $46 \%$ share in industry and $8.8 \%$ in the services sector. In services, the sub-sectors with relatively high levels of regular employees are software and financial services. This can be attributed to the specialized skills needed in these sectors and also regulatory reasons in the case of banking. But telecom stands out as one service sector with a high $46 \%$ share for contract workers.

In industry, temporary workers account for a higher share due to labour-intensive jobs and also because current employment laws resemble a marriage where divorce is not possible, says Manish Sabharwal, Chairman- Team Lease Services.

In the automobile industry, where labour unrest has been more visible in recent years, the ratio is high at $47 \%$ but it's even higher in sectors such as energy and utilities $(54 \%)$ and in cement (52\%). In the engineering sector, Larsen and Toubro Ltd (L\&T) skews the total both due to its size and the fact that its engineering services division recruits temporary workers on a project basis. Excluding it, the sector has a ratio of $22 \%$ but including L\&T's figures takes it up to $75 \%$. Sectors such as pharmaceuticals and consumer goods, too, have relatively lower levels.

Finally, if India's topmost companies have such a high level of contract labour, we can only imagine how high the level of casualization will be among smaller firms.

\section{INDIAN GOVT POLICY OF 2018 IN CONTEXT OF CONTRACTUAL LABOUR}


The Union government is planning to take measures to ensure companies do not convert their full-time workers into contract employees by misusing the proposed fixed-term contract framework. One of them is to ensure that permanent employees in an establishment are protected in such a way that they are not converted into fixed-term workers after we bring in the new law," a labour and employment ministry official said on condition of anonymity. Officials said safeguard-related provisions would be included in the executive order on fixedterm employment, likely to be issued next month. The move is an outcome of a consultation meeting held on February 152018 by the ministry with representatives of state governments, trade unions and industry. All the 12 state governments represented in the meeting were in favour of fixed-term contracts. Three trade unions, the RSS-affiliated Bharatiya Mazdoor Sangh, the National Front of Indian Trade Unions, and the Trade Union Coordination Centre, also supported the move, apart from employers' associations, according to sources. Other trade unions, however, walked out of the meeting as a mark of protest over not holding consultations before announcing the move in the Union Budget .In the Budget for 2018-19, Finance Minister Arun Jaitley announced the government's decision to allow hiring workers on fixed-term contracts for all employers. Fixed-term contracts allow industries to hire workers for short-term assignments and terminate their services once the project is completed.

The government is waking up to the reality of flexistaffing. It recently allowed temporary workers in the garment industry. The decision to set the minimum wage of Rs 10,000 a month for contract workers is another step in that direction. "Contract work is now a reality; the government understands that, and is working towards facilitating it," noted Shankar Agarwal, secretary in the labour and employment minister.

\section{CONCLUSION}

The Make in India campaign is a powerful agenda to transform India into a global manufacturing hub. However, we assume that Labour issues will be the bottleneck into its success. It is a vital role of the management of the company to ensure that they create guidelines for their HR/Plant managers which will lay down a code of conduct and ensure that the contract workers are dealt with in a fair and equal manner as that of permanent workers. Role of HR Department is very crucial in attracting selecting and retaining the manpower of the company, it may be the on roll employees, workers or contractual employees. It is inevitable that HR Department should ensure to identify execute best HR Practices covering entire range of employees. However in many industries, the cardinal focus of HR practices lies for only on roll employees and permanent workers. Whereas HR practices for contractual labour are very limited. And in most of the companies contractual manpower are not treated fairly.

HR Department philosophy says that employees are assets of the organization and must be retained and developed for greater productivity with their job satisfaction. Hence the contractual manpower should also be given due weightage while framing the HR practices and efforts must be made by HR Department to bring the contractual manpower into main stream.

\section{REFERENCES:}

1) Labour Laws (2012) Prof P.A. Noronha, Anjali Mandke, Mahesh Deshpande pg 42-747

2) Mrs. Paramita Ray Contract Laboursystem In India: Issues And Perspectives, International Journal of Law and Legal Jurisprudence Studies :ISSN:2348-8212:Volume 3 Issue 3

3) Neeraj Dubey Joint Partner, Lakshmikumaran \& Sridharan, Bangalore Engaging Contract Labour: The prerequisites and the pitfalls

4) https://blog.ipleaders.in/regulatory-overview-ofcontract-labour-in-india/

5) http://www.rediff.com/money/report/indiascontract-labour-laws-need-to-catch-up-withreality/20160906.html

6) (http://www.arthapedia.in/index.php?title=Contrac t_Labour)

7) REPORT ON Working conditions of the contract workers in Petroleum Refineries and Oil fields 2009-11

8) Labour Bureau

9) Hindustan Times March 2014.

10) http://www.businessstandard.com/article/economy-policy/govt-toensure-firms-do-not-convert-employees-intocontract-workers-118022800044_1.html 